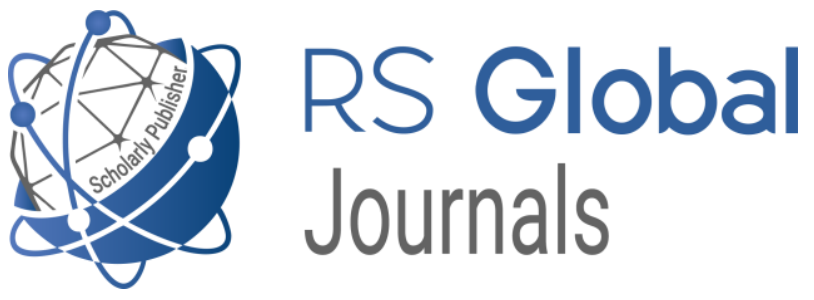

Scholarly Publisher

RS Global Sp. z O.O.

ISNI: 0000000484952390

Dolna 17, Warsaw, Poland 00-773

Tel: +48226022703

Email: editorial_office@rsglobal.pl

JOURNAL International Journal of Innovative Technologies in Social Science

p-ISSN

2544-9338

e-ISSN

2544-9435

PUBLISHER

RS Global Sp. z O.O., Poland

ARTICLE TITLE

AUTHOR(S)

ARTICLE INFO

DOI

RECEIVED

ACCEPTED

PUBLISHED

LICENSE

\section{PSYCHOLOGICAL FACTORS OF SLEEP QUALITY}

Denisiievska Anna

Denisiievska Anna. (2021) Psychological Factors of Sleep Quality. International Journal of Innovative Technologies in Social Science. 1(29).

doi: 10.31435/rsglobal_ijitss/30032021/7493

https://doi.org/10.31435/rsglobal_ijitss/30032021/7493

27 January 2021

19 March 2021

24 March 2021

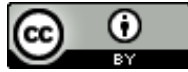

This work is licensed under a Creative Commons Attribution

4.0 International License.

(C) The author(s) 2021. This publication is an open access article. 


\title{
PSYCHOLOGICAL FACTORS OF SLEEP QUALITY
}

\author{
Denisiievska Anna, PhD student of the Department of Psychodiagnostics and Clinical Psychology, \\ Taras Shevchenko National University of Kyiv, Ukraine, \\ ORCID ID: https://orcid.org/0000-0001-8249-1568
}

DOI: https://doi.org/10.31435/rsglobal_ijitss/30032021/7493

\section{ARTICLE INFO}

Received 27 January 2021

Accepted 19 March 2021

Published 24 March 2021

\section{KEYWORDS}

sleep, sleep quality, subjective sleep quality, sleep disturbance, psychological factors.

\begin{abstract}
The article describes some psychological factors of sleep quality. Theoretical analysis of psychological factors that affect the quality of sleep is presented. Sleep quality is an important part of a person's overall health. Sleep problems can be associated with decreased physical and mental health, limitations in daily activities, cognitive impairment. Given these consequences, there is a need for a better understanding of the factors associated with the improvement and deterioration of sleep quality. The relevance of this problem in the context of modern research. The results of an empirical study that reveals the relationship between sleep quality and some psychological factors are highlighted. It was found that the average score of sleep quality indicates unsatisfactory sleep quality. It was found that there are significant differences between the groups of subjects with satisfactory and unsatisfactory indicators of the overall score of sleep quality on the scales of neuroticism and depression. In people who are dissatisfied with the quality of sleep, the level of neuroticism is close to high and there is moderate depression. The relationships between sleep quality indicators and psychological factors have been identified, and their features have been analyzed. In general, these relationships demonstrate: emotional inadequacy does not contribute to a better subjective quality of sleep; depressive or anxious symptoms, emotional instability do not contribute to rapid falling asleep, but contribute to sleep disorders and daytime dysfunction; anxious characteristics affect the reduction of sleep time.
\end{abstract}

Citation: Denisiievska Anna. (2021) Psychological Factors of Sleep Quality. International Journal of Innovative Technologies in Social Science. 1(29). doi: 10.31435/rsglobal_ijitss/30032021/7493

Copyright: (C) 2021 Denisiievska Anna. This is an open-access article distributed under the terms of the Creative Commons Attribution License (CC BY). The use, distribution or reproduction in other forums is permitted, provided the original author(s) or licensor are credited and that the original publication in this journal is cited, in accordance with accepted academic practice. No use, distribution or reproduction is permitted which does not comply with these terms.

Постановка проблеми. Тема якості сну набуває все більшої зацікавленості у суспільстві. Актуальність у цю тему додає вже давній інтерес до здорового способу життя. Існують різні способи та підходи до покращення якості сну. Часто вони пов'язані з гігієною сну. Серйозно на сон та його якість впливають соматичні та психічні хвороби, про які людина може не здогадуватися. Також на особливості сну та його якість можуть впливати деякі психологічні фактори та особливості особистості.

Поняття якості сну досі недостатньо досліджено, але при цьому часто і широко використовується. Деякі вчені (Akerstedt et al., 1994) відзначали, що не має великої бази систематичних знань про те, що є суб'єктивно хорошим сном і як його потрібно вимірювати. Буіс (Buysse et al., 1989) називає якість сну складним явищем, яке складно визначити і виміряти об'єктивно.

Погана якість сну характеризується проблемами із засинанням, нічними пробудженнями, поганим настроєм під час прокидання (Chen et al., 2015). Тобто тема якості сну це й важливе питання для загального здоров'я людини. Проблеми сну можуть бути пов'язані зі зниженням фізичного та психічного здоров'я, обмеження у повсякденній діяльності, когнітивними порушеннями. Враховуючи ці шкідливі наслідки, існує потреба у кращому розумінні факторів, пов'язаних з покращенням та погіршенням якості сну.

Іноді якість сну ототожнюють 3 кількістю сну, але ці поняття, насправді, не пов'язані. Також не можна порівнювати об'єктивну та суб'єктивну оцінку якості сну. Дослідження за допомогою об'єктивних методів (наприклад, полісомнографія), демонструє, що об'єктивна та 
суб'єктивна оцінки відрізняються (Moul et al., 2002). Тобто людина може оцінювати якість свого сну як незадовільну, але за допомогою об'єктивних методів діагностується достатньо гарна якість сну та навпаки. Едінгер і його колеги (Edinger et al., 2000) розрізняють дві групи: групу суб'єктивної безсоння, яка відповідала критеріям безсоння, але мала нормальний сон за полісомнографією i групу суб'єктивно задоволених сном, які відповідали критеріям «хорошої якості сну», але об'єктивно мали порушення сну за полісомнографією. Цікавий факт, що психологічні фактори розрізняють ці дві групи: в групі суб'єктивної безсоння проявляється пригнічений настрій, занепокоєння, більше дисфункціональних переконань на рахунок сну, порівняно з групою суб'єктивно задоволених сном. Ці результати підкреслюють складність поняття якість сну і важливість розуміння суб'єктивного значення якості сну (Harvey et al., 2008). Якість сну це комплексний феномен, на який впливають такі показники, як його тривалість, час засипання, кількість пробуджень за ніч, час відходу до сну і час пробудження, структура сну, ефективність сну (Akerstedt et al., 1994). Розвиток порушення сну може бути пов'язано з широким колом соматичних, психічних і інших чинників. Також у розвитку порушень сну, особливо суб'єктивних, беруть участь психологічні чинники (Тхостов \& Рассказова, 2009). В експериментальних роботах зазначають, що порушення сну можуть бути викликані в ситуації стресу у здорових досліджуваних.

В ретроспективних дослідженнях хворих у більшості випадків вдається виявити стресові події, пов'язані з початком хвороби або погіршенням стану. Однак важливіша роль психологічних факторів при хроніфікації розладів сну, наприклад, інсомнії. Згідно реконцептуалізації когнітивної моделі інсомнії Е. Харвей, перехід інсомнії в хронічну форму залежить не стільки від частоти порушень сну, скільки від тривоги щодо сну. Об'єктивні та суб'єктивні характеристики сну при гострій інсомнії не дозволяють прогнозувати ії подальший перебіг. Навпаки, в проспективних дослідженнях психологічні фактори (тривожність, депресивність, уявлення про сон та безсоння, думок перед сном) передбачають складність інсомнії, а вплив на них за допомогою психотерапії призводить до покращення стану хворих. Симптоми інсомнії викликають у людини тривогу за свій сон і страх не заснути, пов'язані в тому числі з дисфункціональними переконаннями по відношенню до сну (Harvey \& Espie, 2004), що призводить до виникнення хронічної форми інсомнії.

В сучасному когнітивному підході в психології накопичені емпіричні дані в підтримку важливої ролі емоційних, когнітивних та поведінкових факторів у провокації та хроніфікації порушення сну. При цьому є відносно давно відомі факти про зв'язок порушень сну 3 неспецифічними факторами - стресом, депресією та тривогою. В той же час дані про роль специфічних феноменів - тривоги та переконань по відношенні до сну, думок перед сном, поведінкою з регуляції свого сну - 3'явились відносно нещодавно, притому вони розглядаються переважно як вторинні фактори хроніфікації розладів сну.

Постановка завдання. Мета статті - визначити та проаналізувати психологічні фактори якості сну та суб'єктивної якості сну.

Виклад основного матеріалу дослідження. У досліджені взяли участь 89 осіб, віком від 18 до 47 років. У якості діагностичного інструментарію використано такі методики: Пітсбургський опитувальник якості сну (PSQI), Особистісний опитувальник Айзенка (EPQ), Шкала депресії Бека, Шкала тривоги Бека. Для статистичної обробки даних було використано методи описової статистики, U-критерій Манна-Уітні та кореляційний аналіз (коефіцієнт кореляції Спірмена).

Опитувальник PSQI складається 37 компонентних показників: суб'єктивна якість сну, латентність сну, тривалість сну, ефективність сну, порушення сну, виживання снодійних та денна дисфункція. Оцінки компонентів варіюються від 0 (без утруднень) до 3 (важкі ускладнення) і в підсумку дають загальну оцінку в діапазоні від 0 до 21. Загальний бал $>5$ вказує на незадовільну якість сну, бал $\leq 5$ вказує на хорошу якістю сну.

Середній показник загального балу якості сну серед наших респондентів дорівнює 6,9. Далі ми детальніше розберемо компоненти загальної якості сну. За допомогою описової статистики частоти (frequency) бачимо розподіл загального балу якості сну серед нашої вибірки (рис.1).

Більша частина вибірки знаходиться за межею незадовільної якості сну $-59,6 \%$. Найменший та найвищий бал серед вибірки демонструють 2,1\% досліджуваних.

Для детального розуміння значення всіх компонентів опитувальника представлено таблицю з варіантами відповідей та відсотковим співвідношенням кількості осіб на кожний варіант (таблиця 1). 


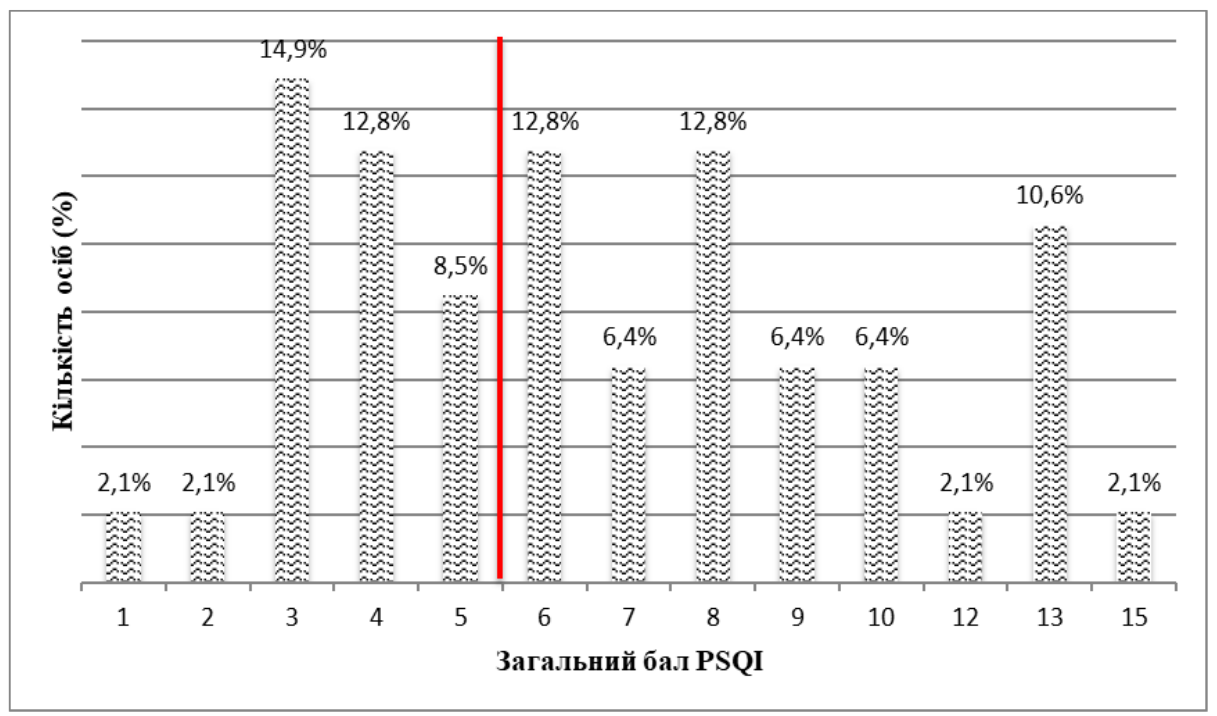

Рис.1. Загальний бал якості сну

Таблиця 1. Якість сну та оцінка його компонентів

\begin{tabular}{|c|c|c|}
\hline Компоненти & Відповіді & Досліджувані (\%) \\
\hline \multirow{4}{*}{ Суб'єктивна якість сну } & Дуже добре & 4,3 \\
\hline & Достатньо добре & 57,4 \\
\hline & Скоріше погано & 23,4 \\
\hline & Дуже погано & 14,9 \\
\hline \multirow{4}{*}{ Латентність сну } & 0 & 21,3 \\
\hline & 1 & 36,2 \\
\hline & 2 & 25,5 \\
\hline & 3 & 17 \\
\hline \multirow{4}{*}{ Тривалість сну } & $>7$ годин & 53,2 \\
\hline & 6-7 годин & 31,9 \\
\hline & 5-6 годин & 6,4 \\
\hline & $<5$ годин & 8,5 \\
\hline \multirow{4}{*}{ Ефективність сну } & $>85 \%$ & 83 \\
\hline & $75-84 \%$ & 12,8 \\
\hline & $65-74 \%$ & 4,3 \\
\hline & $<65 \%$ & 0 \\
\hline \multirow{4}{*}{ Порушення сну } & 0 & 10,6 \\
\hline & 1 & 70,2 \\
\hline & 2 & 19,1 \\
\hline & 3 & 0 \\
\hline \multirow{4}{*}{ Вживання снодійних } & Ні разу протягом останнього місяця & 74,5 \\
\hline & Менше, ніж один раз у тиждень & 10,6 \\
\hline & Один або два рази у тиждень & 4,3 \\
\hline & Три або більше разів у тиждень & 10,6 \\
\hline \multirow{4}{*}{ Денна дисфункція } & 0 & 8,5 \\
\hline & 1 & 46,8 \\
\hline & 2 & 34 \\
\hline & 3 & 10,6 \\
\hline
\end{tabular}

Далі за допомогою U-критерію Манна-Уітні ми порівняли респондентів із задовільним та незадовільним показниками загального балу якості сну. Виявлено, що існують значущі відмінності між групами досліджуваних за показниками «нейротизм» $(\mathrm{p}=0,001)$ та «депресія» $(\mathrm{p}=0,001)$. За показниками «екстраверсія-інтроверсія» $(\mathrm{p}=0,913)$, «психотизм» $(\mathrm{p}=0,576)$ та «тривога» $(\mathrm{p}=0,052)$ значущих відмінностей за U-критерієм Манна-Уітні не виявлено.

Середні бали цих показників (рис.2) свідчать про таке:

- за показником «екстраверсія-інтроверсія» не має статистично значущої різниці між групами, досліджувані демонструють рівень амбівалентності за шкалою;

- за показником «психотизм» не має статистично значущої різниці між групами, досліджувані демонструють відсутність даної риси; 
- за показником «тривога» не має статистично значущої різниці між групами, досліджувані демонструють незначний рівень тривоги, який трохи вище у людей, незадоволених якістю сну;

- за показником «нейротизм» обидві групи демонструють середній рівень, але у людей, незадоволених якістю сну, рівень нейротизму наближений до високого, що означає більш виражений нейротизм, у порівнянні з людьми, задоволеними якістю сну;

- за показником «депресія» у людей, незадоволених якістю сну, виявлена помірна депресія, а у людей, задоволених якістю сну, депресивні симптоми, натомість, відсутні.

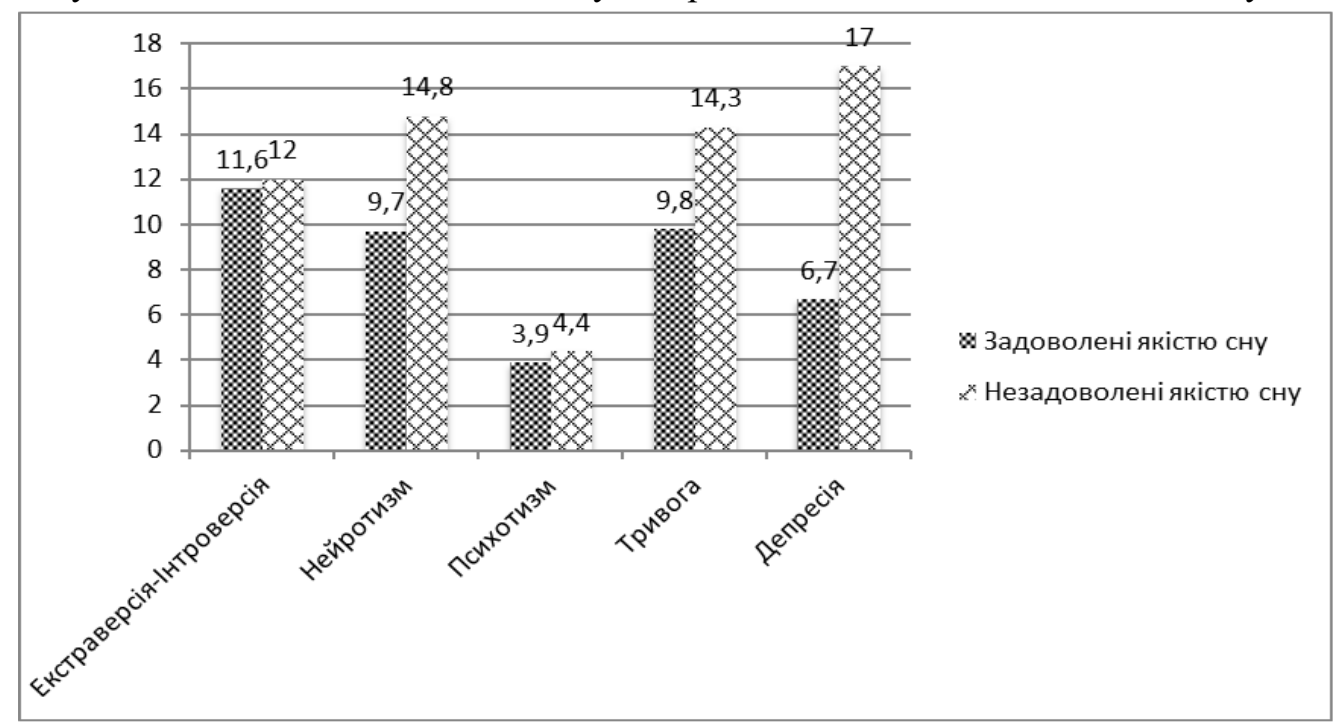

Рис.2. Середні показники за психологічними факторами

Для того, щоб виявити взаємозв'язок між показниками методик, використаємо кореляційний аналіз (коефіцієнт кореляції Спірмена). Результати кореляційного аналізу наведені у таблиці 2.

У процесі кореляційного аналізу було виявлено такі статистично значущі взаємозв'язки:

Слабку позитивну кореляцію між змінними «суб'єктивна якість сну» та «психотизм» $\left(0.333^{*}, \mathrm{p}=0.022\right)$. Тобто, чим вищий рівень психотизму, тим нижчий рівень суб'єктивної якості сну та навпаки. Це означає, що людина, яка схильна до емоційної неадекватності, не схильна до кращої суб'єктивної якості сну та її оцінки.

Слабку позитивну кореляцію між змінними «латентність сну» та «нейротизм» $(0.367 *$, $\mathrm{p}=0.011)$. Помірні позитивні кореляції між змінними «латентність сну» та «тривога» $(0.491 * *$, $\mathrm{p}=0.000)$, «депресія» $(0.469 * *, \mathrm{p}=0.001)$. Тобто, чим вищий рівень показників нейротизму, тривоги та депресії, тим нижчий рівень латентності сну та навпаки. Це пояснюється тим, що людина, яка має депресивні або тривожні симптоми, емоційно нестійка, не засинає швидко, їі можуть хвилювати різні думки, які заважають засинати.

Слабку позитивну кореляцію між змінними «тривалість сну» та «тривога» $(0.362$, $\mathrm{p}=0.012)$. Тобто, чим вищий рівень тривоги, тим нижча тривалість сну та навпаки. Це означає, що людина 3 тривожними характеристиками, за рахунок важкого засинання, нічних пробуджень, раннього пробудження зранку, скорочує свій час сну.

Помірні позитивні кореляції між змінними «порушення сну» та «нейротизм» $(0.361 *$, $\mathrm{p}=0.013)$, «тривога» $\left(0.399^{* *}, \mathrm{p}=0.005\right)$, «депресія» $\left(0.336^{*}, \mathrm{p}=0.021\right)$. Тобто, чим вищий рівень показників нейротизму, тривоги та депресії, тим вищий рівень порушень сну та навпаки. Це пояснюється тим, що людина, яка має депресивні або тривожні симптоми, емоційно нестійка схильна до порушень сну.

Слабку позитивну кореляцію між змінними «вживання снодійних» та «нейротизм» $(0.342 *, \mathrm{p}=0.019)$. Тобто, чим вищий рівень показників нейротизму, тим вищий рівень порушень сну та навпаки. Це пояснюється тим, що людина, яка не відчуває себе здоровою та емоційно стійкою, вірогідніше буде використовувати ліки, в тому числі снодійні.

Слабку позитивну кореляцію між змінними «денна дисфункція» та «тривога» $(0.334 *$, $\mathrm{p}=0.022)$. Помірні позивні кореляції між змінними «денна дисфункція» та «депресія» $(0.449 * *$, $\mathrm{p}=0.002)$, «нейротизм» $(0.521 * *, \mathrm{p}=0.000)$. Тобто, чим вищий рівень показників нейротизму, 
тривоги та депресії, тим нижчий рівень денної дисфункції та навпаки. Це пояснюється тим, що людина, яка має депресивні або тривожні симптоми, емоційно нестійка, вірогідно має поганий сон та незадовільно оцінює його якість. Тому вдень функціонування погіршене, внаслідок не повного відновлення за ніч.

Таблиця 2. Кореляційний аналіз (коефіцієнт кореляції Спірмена)

\begin{tabular}{|l|c|c|c|c|}
\hline & Нейротизм & Психотизм & Тривога & Депресія \\
\hline Суб'єктивна якість сну & & $0.333^{*}$ & & \\
\hline Латентність сну & $0.367^{*}$ & & $0.491^{* *}$ & $0.469^{* *}$ \\
\hline Тривалість сну & & & $0.362^{*}$ & \\
\hline Порушення сну & $0.361^{*}$ & & $0.399^{* *}$ & $0.336^{*}$ \\
\hline Вживання снодійних & $0.342^{*}$ & & & \\
\hline Денна дисфункція & $0.521^{* *}$ & & $0.334^{*}$ & $0.449^{* *}$ \\
\hline
\end{tabular}

* Кореляція є значущою на рівні 0,05.

** Кореляція є значущою на рівні 0,01 .

Висновки. Визначено та проаналізовано психологічні фактори якості сну.

Середній показник загального балу якості сну свідчить про незадовільну якість сну.

Виявлено, що існують значущі відмінності між групами досліджуваних із задовільним та незадовільним показниками загального балу якості сну за показниками нейротизм та депресія. У людей, незадоволених якістю сну, рівень нейротизму наближений до високого та наявна помірна депресія.

Середній показник екстраверсії-інтроверсії знаходиться на рівні амбівалентності, середній показник психотизму демонструє відсутність даної риси, рівень тривоги трохи вище у людей, незадоволених якістю сну.

Виявлені взаємозв’язки між показниками якості сну та психологічними факторами, проаналізовано їх особливості. В цілому, ці взаємозв'язки демонструють: емоційна неадекватність не сприяє кращій суб'єктивній якості сну; депресивні або тривожні симптоми, емоційна нестійкість не сприяють швидкому засинанню, а сприяють порушенням сну та денній дисфункції; тривожні характеристики впливають на скорочення часу сну.

Базуючись на результатах емпіричного дослідження і вивченні теоретичного матеріалу, виявлені взаємозв'язки психологічних факторів з якістю сну. Перспективи подальших досліджень бачимо у розширенні можливих психологічних факторів, які можуть впливати на якість сну.

\section{ЛІТЕРАТУРА}

1. Akerstedt, T., Hume, K., Minors, D., \& Waterhouse, J. (1994). The meaning of good sleep: a longitudinal study of polysomnography and subjective sleep quality. Journal of sleep research, 3(3), 152-158. Retrieved from https://doi.org/10.1111/j.1365-2869.1994.tb00122.x

2. Buysse, D. J., Reynolds, C. F., 3rd, Monk, T. H., Berman, S. R., \& Kupfer, D. J. (1989). The Pittsburgh Sleep Quality Index: a new instrument for psychiatric practice and research. Psychiatry research, 28(2), 193-213. Retrieved from https://doi.org/10.1016/0165-1781(89)90047-4

3. Chen, J. H., Waite, L., Kurina, L. M., Thisted, R. A., McClintock, M., \& Lauderdale, D. S. (2015). Insomnia symptoms and actigraph-estimated sleep characteristics in a nationally representative sample of older adults. The journals of gerontology. Series A, Biological sciences and medical sciences, 70(2), 185192. Retrieved from https://doi.org/10.1093/gerona/glu144

4. Edinger, J. D., Fins, A. I., Glenn, D. M., Sullivan, R. J., Jr, Bastian, L. A., Marsh, G. R., Dailey, D., Hope, T. V., Young, M., Shaw, E., \& Vasilas, D. (2000). Insomnia and the eye of the beholder: are there clinical markers of objective sleep disturbances among adults with and without insomnia complaints?. Journal of consulting and clinical psychology, 68(4), 586-593.

5. Harvey, A. G., Stinson, K., Whitaker, K. L., Moskovitz, D., \& Virk, H. (2008). The subjective meaning of sleep quality: a comparison of individuals with and without insomnia. Sleep, 31(3), 383-393. Retrieved from https://doi.org/10.1093/sleep/31.3.383

6. Harvey, K. J., \& Espie, C. A. (2004). Development and preliminary validation of the Glasgow Content of Thoughts Inventory (GCTI): a new measure for the assessment of pre-sleep cognitive activity. The British journal of clinical psychology, 43(Pt 4), 409-420. Retrieved from https://doi.org/10.1348/0144665042388900

7. Moul, D. E., Nofzinger, E. A., Pilkonis, P. A., Houck, P. R., Miewald, J. M., \& Buysse, D. J. (2002). Symptom reports in severe chronic insomnia. Sleep, 25(5), 553-563.

8. Тхостов, А. Ш., \& Рассказова, Е. И. (2009). Психологические факторы хронической инсомнии и субъективная и объективная картина сна. Вестник Томского государственного университета, (323), 331-335. 